\title{
Influence of Photoperiodic Night Interruption on Sustainable Potted Flower Production of Chrysanthemum cv. Snowball
}

\author{
Tanya Thakur* and H.S. Grewal \\ Department of Floriculture and Landscaping, \\ Punjab Agricultural University, Ludhiana, Punjab, India \\ *Corresponding author
}

\section{A B S T R A C T}

\section{Keywords}

Chrysanthemum, Photoperiodic, Night interruption,

Snowball,

Regulation, Sustainable

Article Info

Accepted:

15 January 2018

Available Online:

10 Februarv 2018
Chrysanthemum morifolium Ramat is photoperiodically controlled ornamental crop, therefore, the monitoring of photoperiod provides an efficient crop schedule according to demand of flowers in the market. The six different photoperiodic night interruption treatments i.e. control, <5 second flash, 30-, 60-, 90- and 120- minute were used to study the influence on development of standard potted Chrysanthemum cultivar Snowball. The vegetative growth of the plant i.e. plant height, number of leaves and root suckers per plant were positively affected with increased night interruption duration. The flower bud appearance was significantly delayed in $<5 \mathrm{sec}$. night interruption ( 85.62 days) than the control (62.52 days), whereas, there was no flower bud appearance (rosette formation of leaves) in all the other treatments. The flowering time was delayed from Mid- November to Mid- December i.e. by around one month as the duration of night interruption was increased from control to $<5 \mathrm{sec}$. night interruption. The flower quality was negatively affected with reduction in duration of flowering at $<5 \mathrm{sec}$. night interruption, whereas, flower diameter was increased. Therefore, the present study on influence of night interruption durations would be helpful to schedule the flowering time in Chrysanthemum cultivar Snowball by around one month with increased plant growth for sustainable potted flower production.

\section{Introduction}

Chrysanthemum morifolium Ramat is one of the important photoperiodically controlled ornamental crops produced as both cut flower and pot plant (Van Der Ploeg and Heuvelink, 2006). Photoperiod, day light exposure of plants, regulates morphological development in many floriculture crops like Poinsettia, Kalanchoe etc. and commercial growers provide long days through artificial lighting to maintain vegetative growth for cutting production in Chrysanthemum (Dole and Wilkins, 2005) and to regulate flowering of photoperiod-sensitive species (Blanchard and Runkle, 2009; Chen et al., 2003; Mattson and Erwin, 2005; Yamada et al., 2008). Chrysanthemum is a short-day plant with a critical day length of 13.5 hours (Post, 1931; Furuta, 1954), so long-days (day-length $>12$ 
h) are maintained for $10-25$ days so that the plants grow vegetatively (Carvalho, 2003) and then plants are grown under short-day (day length $<12 \mathrm{~h}$ ) leading to flower induction and development. In the open cultivation, the flowering of Chrysanthemum is confined only to limited period from October to December thus, the monitoring of photoperiod provides growers with an efficient crop schedule according to demand of flowers in the market. The flowering of Chrysanthemum was inhibited by illuminating the plants with fluorescent or incandescent lamps by night interruption ('night break') with red light $(660 \mathrm{~nm})$ but subsequently irradiated far-red light $(730 \mathrm{~nm})$ induced the flowering of Chrysanthemum, this photoreversible flowering responses is regulated by the plant photoreceptor phytochrome B (Hong, 2013). The incandescent (INC) lamp emits more far red (FR; 700-800 nm) than red (R; 600-700 nm) light and has R: FR of about 0.7 (Thimijan and Heins, 1983). Supplemental lighting that had a low R: FR to extend the day produced taller plants (Piringer and Cathey, 1960). This experiment was designed to investigate the effect of photoperiodic night interruption on sustainable flower production of Chrysanthemum.

\section{Materials and Methods}

The experiment was conducted at Department of Floriculture and Landscaping, Punjab Agricultural University, Ludhiana during 2014-15.

\section{Experimental layout}

The terminal cuttings were taken from the mother stock plants pinched in end of May to encourage more number of axillary shoots of potted standard Chrysanthemum cultivar Snowball. The terminal cuttings $(5-7 \mathrm{~cm})$ were treated with IBA $400 \mathrm{mg} / \mathrm{l}$ and planted in burnt rice husk for rooting in June-July. The rooted cuttings were then transplanted during end July in the pots (6") containing mixture of soil and FYM (2:1) along with diammonium phosphate incorporated as a basal dose @ $1 \mathrm{~kg} / 100$ cubic feet. The plants were given night interruption (NI) treatments using incandescent bulbs (single 100 watt, $1.25 \mathrm{~m}$ above pot) for 2 months starting from $20^{\text {th }}$ September till $20^{\text {th }}$ November turned on from 22:00 to 24:00. The plants were kept under natural short day open conditions thereafter. The night interruption were given starting from 22:00 to $24: 00$ as per the treatments- (i) $\mathrm{T} 0=$ control, (ii) $\mathrm{T} 1=<5 \mathrm{sec}$ (flash of light), (iii) $\mathrm{T} 2=30 \mathrm{~min}$, (iv) $\mathrm{T} 3=60$ min, (v) T4 = $90 \mathrm{~min}$ and (vi) $\mathrm{T} 5=120 \mathrm{~min}$.

\section{Statistical analysis}

The experiments were conducted as per treatments in completely randomized design (CRD) with three replications comprising five pots per replication. The effect of different durations of night interruption on vegetative growth (at 15 days interval) and floral parameters were recorded and statistical analysis was performed using SAS software and treatment means were compared using Duncan Multiple Range Test (DMRT) at 5\% level of significance (Duncan, 1955).

\section{Results and Discussion}

\section{Vegetative growth}

In Chrysanthemum morifolium cv. Snowball, the photoperiodic treatments significantly $(\mathrm{p}<0.05)$ influenced the plant height, number of leaves 45, 60 and 75 days after planting (DAP) and root suckers per plant (Table 1). The plant height 45, 60 and 75 DAP, in all photoperiodic treatments were better than the control (24.25, 47.83 and $60.26 \mathrm{~cm}$, respectively). The maximum plant height 45 DAP, was obtained in $120 \mathrm{~min}$. NI. The plant 
height 60 DAP, was maximum at $120 \mathrm{~min}$. NI $(63.46 \mathrm{~cm})$ followed by $90-$ and $60 \mathrm{~min}$. NI (61.10 and $60.19 \mathrm{~cm}$, respectively). The plant height 75 DAP, was maximum in $120 \mathrm{~min}$. NI $(94.64 \mathrm{~cm})$, followed by $90-, 60-$ and $30 \mathrm{~min}$. NI $(92.81,89.91$ and $86.40 \mathrm{~cm}$, respectively). The number of leaves per plant 45, 60 and 75 DAP, in all photoperiodic treatments were significantly better than the control (12.77, 20.77 and 24.13 , respectively). The number of leaves 45 DAP, were maximum in $120 \mathrm{~min}$. NI (20.21) followed by $90-$ and $60 \mathrm{~min}$. NI (18.17 and 17.13) which were at par among them. The number of leaves 60 DAP, was maximum in $120 \mathrm{~min}$. NI (26.55) followed by 90- and $60 \mathrm{~min}$. NI (24.77 and 23.16). The numbers of leaves 75 DAP, increased significantly with 60-, 90- and $120 \mathrm{~min}$. NI (28.70, 30.07 and 32.24, respectively). The number of root suckers per plant was significantly better in 90- and $120 \mathrm{~min}$. NI (11.18 and 12.01) than the other treatments.

The vegetative parameters i.e. plant height, number of leaves and root suckers per plant increased with increase in duration of photoperiodic night interruption. In Chrysanthemum for commercial production of cut stems, the plants maintained under long day conditions and optimum night temperature promoted vegetative growth and stem length before flower induction grown for year around flowering with long stems (Datta and Ramadas, 2000; Datta, 2006; Datta and Gupta, 2012). The increased plant height and growth rate resulted in enhanced photosynthetic activities under artificial long day conditions accompanied by accumulation of carbohydrate and nitrogen in the treated plants (Datta and Ramadas, 2000). Kurilcik et $a l$. , (2008) reported that the shoot length and number of leaf increased with the increase of the photoperiod from $8 \mathrm{~h}$ to $24 \mathrm{~h}$. Similar results had been reported earlier also with respect to effect of photoperiod on vegetative growth in Chrysanthemum (Hayashi et al.,
2001; Jaime and Silva, 2003, Karlovic et al., 2004; Kahar, 2008).

\section{Flowering parameters}

In Chrysanthemum morifolium cv. Snowball, the effect of different photoperiodic treatments was significant $(\mathrm{p}<0.05)$ on the days to flower bud appearance, color break stage and full bloom, where non- significant with respect to duration of flowering and flower diameter (Table 2). The days taken to flower bud appearance from planting was significantly more in < $5 \mathrm{sec}$ NI (85.62 days in end November) than the control (62.52 days in end October). There was no flower bud appearance (rosette formation of leaves) in all the other treatments, might be due to genetic factor or low temperature at the time of bud appearance. The days taken to color break stage from planting was significantly better in $<5 \mathrm{sec}$. NI (108.57 days in $3^{\text {rd }}$ week of December) than the control (75.20 days) and color break stage started in $2^{\text {nd }}$ week of November. The day taken to full bloom from planting was significantly more in $<5 \mathrm{sec}$. NI (135.72 days in mid-January) than the control (108.22 days) and full bloom appeared in mid-December. There was reduction in duration of flowering at $<5 \mathrm{sec}$. NI (10.60 days), at par with the control (12.31 days). The flower diameter was more in $<5 \mathrm{sec}$. NI $(15.40 \mathrm{~cm})$ as compared to the control (14.22 $\mathrm{cm})$ and at par among themselves.

It was observed that night interruption beyond $<5 \mathrm{sec}$. completely inhibited the flower bud appearance resulting in rosette formation of leaves, which might be due to sensitivity of cultivar Snowball to very low temperature at time of bud appearance during January $\left(15.5^{0} \mathrm{C}\right)$. These results are in conformity with the findings of Furuta (1954) reported that buds do not develop normally under longer photoperiods. 
Table.1 Effect of photoperiod on vegetative growth of Chrysanthemum cv. Snowball

\begin{tabular}{|c|c|c|c|c|c|c|c|c|c|}
\hline \multirow{2}{*}{$\begin{array}{l}\text { Treatments } \\
\text { (Duration of } \\
\text { NI) }\end{array}$} & \multicolumn{4}{|c|}{ Plant height (cm) } & \multicolumn{4}{|c|}{ No. of leaves/plant } & \multirow{2}{*}{$\begin{array}{l}\text { No. of root } \\
\text { sucker/plant }\end{array}$} \\
\hline & 30 DAP & 45 DAP & 60 DAP & 75 DAP & 30 DAP & 45 DAP & 60 DAP & 75 DAP & \\
\hline Control & $10.91 \mathrm{a}$ & $24.25 \mathrm{c}$ & $47.83 \mathrm{~b}$ & $60.26 c$ & $9.57 \mathrm{a}$ & $12.77 \mathrm{~b}$ & $20.77 \mathrm{~d}$ & $24.13 \mathrm{~d}$ & $8.12 \mathrm{c}$ \\
\hline$<5$ sec. & $11.79 \mathrm{a}$ & $29.23 b c$ & $55.57 \mathrm{ab}$ & $81.06 b c$ & $10.29 \mathrm{a}$ & $16.91 \mathrm{ab}$ & $22.50 \mathrm{~cd}$ & $27.01 \mathrm{~cd}$ & $9.13 \mathrm{bc}$ \\
\hline 30 min. & $12.78 \mathrm{a}$ & $30.56 \mathrm{abc}$ & $58.72 \mathrm{ab}$ & $86.40 \mathrm{ab}$ & $10.09 \mathrm{a}$ & $16.69 \mathrm{ab}$ & $23.16 \mathrm{bc}$ & $28.16 \mathrm{bcd}$ & $10.90 \mathrm{ab}$ \\
\hline $60 \mathrm{~min}$. & $12.73 \mathrm{a}$ & $27.67 \mathrm{bc}$ & $60.19 \mathrm{a}$ & $89.91 \mathrm{ab}$ & $10.53 \mathrm{a}$ & $17.13 \mathrm{a}$ & $23.16 \mathrm{bc}$ & $28.70 \mathrm{bc}$ & $10.42 \mathrm{abc}$ \\
\hline 90 min. & $12.76 \mathrm{a}$ & $33.12 \mathrm{ab}$ & $61.10 \mathrm{a}$ & $92.81 \mathrm{ab}$ & $10.59 \mathrm{a}$ & $18.17 \mathrm{a}$ & $24.77 \mathrm{ab}$ & $30.07 \mathrm{ab}$ & $11.18 \mathrm{a}$ \\
\hline $120 \mathrm{~min}$. & $12.39 \mathrm{a}$ & $36.61 \mathrm{a}$ & $63.46 \mathrm{a}$ & $94.64 \mathrm{a}$ & $9.99 \mathrm{a}$ & $20.21 \mathrm{a}$ & $26.55 \mathrm{a}$ & $32.24 \mathrm{a}$ & $12.01 \mathrm{a}$ \\
\hline F- test & ns & $*$ & $*$ & $*$ & ns & $*$ & $*$ & $*$ & $*$ \\
\hline
\end{tabular}

Table 2.Effect of photoperiod on flowering of Chrysanthemum cv. Snowball

\begin{tabular}{|c|c|c|c|c|c|}
\hline $\begin{array}{c}\text { Treatments } \\
\text { (Duration of } \\
\text { NI) }\end{array}$ & $\begin{array}{l}\text { Days to bud } \\
\text { appearance }\end{array}$ & $\begin{array}{c}\text { Days to colour break } \\
\text { stage }\end{array}$ & Days to full bloom & $\begin{array}{l}\text { Duration of flowering } \\
\text { (days) }\end{array}$ & Flower diameter $(\mathrm{cm})$ \\
\hline Control & $62.52 \mathrm{~b}$ & $75.20 \mathrm{~b}$ & $108.22 \mathrm{~b}$ & $12.31 \mathrm{a}$ & $14.22 \mathrm{a}$ \\
\hline$<5$ sec. & $85.62 \mathrm{a}$ & $108.57 \mathrm{a}$ & $135.72 \mathrm{a}$ & $10.60 \mathrm{a}$ & $15.40 \mathrm{a}$ \\
\hline $30 \mathrm{~min}$. & $-\mathrm{y}$ & $-\mathrm{y}$ & $-\mathrm{y}$ & $-\mathrm{y}$ & $-\mathrm{y}$ \\
\hline $60 \mathrm{~min}$. & $-\mathrm{y}$ & $-\mathrm{y}$ & $-\mathrm{y}$ & $-\mathrm{y}$ & $-\mathrm{y}$ \\
\hline $90 \mathrm{~min}$. & $-\mathrm{y}$ & $-\mathrm{y}$ & $-\mathrm{y}$ & $-\mathrm{y}$ & $-\mathrm{y}$ \\
\hline $120 \mathrm{~min}$. & $-\mathrm{y}$ & $-\mathrm{y}$ & $-\mathrm{y}$ & $-\mathrm{y}$ & $-\mathrm{y}$ \\
\hline F- test & $*$ & $*$ & $*$ & ns & $\mathrm{ns}$ \\
\hline
\end{tabular}

Mean values in each column with the same letter are not significantly different at $\mathrm{p}<0.05$ according to DMRT

$\mathrm{ns}=$ non significant $*$ Significant at $\mathrm{p}<0.05 \_\mathrm{y}$ : plants did not reach the stage of data collection 
Yang et al., 2007 also reported that the Chrysanthemum cv. 'Jinba' failed to bloom under long day treatment. There was reduction in duration of flowering under $<5$ sec. NI due to delayed flowering which coincided with increase in temperature at the time of full opening in month of $1^{\text {st }}$ week of February $\left(16.3^{\circ} \mathrm{C}\right)$. The high temperature increased the respiration rate, depletes the plant of its carbon sources having adverse effect on longevity of the petals (Korfranek and Halevy, 1972) and also exhibited decline in water uptake.

In the terms of overall performance, the vegetative growth i.e. plant height, number of leaves and root suckers per plant significantly increased with increase in duration of photoperiodic night interruption (NI) from $<5$ sec. flash to $120 \mathrm{~min}$., whereas, the increased NI of more than $<5 \mathrm{sec}$. completely inhibited flower bud appearance resulting in rosette formation of leaves. The increased duration of NI significantly reduced the duration of flowering, whereas, increased the flower diameter. Therefore, the present study would be helpful to schedule the flowering time in Chrysanthemum cultivar Snowball by around one month with increased plant growth for sustainable potted flower production.

\section{Acknowledgement}

We acknowledge, Department of Science and Technology(DST), under the Ministry of Science and Technology, Government of India for providing fellowship under the "INSPIRE Programme" to carry out this research work.

\section{References}

Blanchard, M.G., and Runkle, E.S. 2009. Use of a cyclic high-pressure sodium lamp to inhibit flowering of Chrysanthemum and velvet sage. Sci. Horti. 122: 448-454.

Chen, C.L., Tsai, Y.J., Sung, J.M. 2010. Photoperiod effect on flowering and seed setting of Hypericum perforatum. Exploring Agri. 46: 393-400.

Datta, J.P., and Ramadas, S. 2000. Growth, development and flowering of Chrysanthemum (Dendranthema grandiflora Tzelev.) as influenced by long-day exposures. Orissa J. Horti. 28(1): 7-13.

Datta, S.K. 2006. Advances in Ornamental Horticulture. In: Bhattacherjee SK (ed), Pointer Publishers, Jaipur, India, pp: 1-19.

Datta, S.K., and Gupta, V.K. 2012. Year round cultivation of garden Chrysanthemum (Chrysanthemum morifolium Ramat.) through photoperiodic response. Sci. \& Culture. 78(1-2): 71-77.

Dole, J., and Wilkins, H. 2005. Floriculture Principles and Species. $2^{\text {nd }}$ ed. Prentice-Hall, Upper Saddle River, NJ, USA.

Furuta, T. 1954. Photoperiod and flowering of Chrysanthemum morifolium. Proc. Am. Soc. Horti. Sci., 63:457-461.

Hayashi, T., Heins, R.D., Cameron, A.C., and Carlson, W.H. 2001. Ethephon influences flowering, height, and branching of several herbaceous perennials. Sci. Horti., 91(3-4): 305-324.

Jaime, A., and Silva, T. 2003. Chrysanthemum: advances in tissue culture, cryopreservation, postharvest technology, genetics and transgenic biotechnology. Biotech. Adv., 21: 715-766.

Kahar, S.Ab. 2008. Effects of photoperiod on growth and flowering of 
Chrysanthemum morifolium

Ramat cv.

Reagan Sunny. J. Trop. Agri. Food Sci., 36(2): 1-8.

Karlovic, K., Vrsek, I., Sindrak, Z., and Zidovec, V. 2004. Influence of growth regulators on the height and number of inflorescence shoots in the Chrysanthemum cultivar 'Revert'. Agri. Conspectus Sci. 69(2-3):63-66.

Korfranek, A.M., and Halevy ,A.H. 1972. Conditions for opening cut Chrysanthemum flower buds. J. Am. Soc. Horti. Sci., 97: 578- 584.

Kurilcik, A., Dapkuniene, S., Kurilcik, G., Žilinskaite, S., Žukauskas, A., and Duchovskis, P. 2008. Effect of the photoperiod duration on the growth of Chrysanthemum plantlets in vitro. Scientific work of the Lithunian Institute of Horticulture and Lithunian Institute of Agriculture. SodininkysteIrDaržininkyste 27(2): 39-46.

Mattson, N.S., and Erwin, J.E. 2005. The impact of photoperiod and irradiance on flowering of several herbaceous ornamentals. Sci.Horti. 104: 275-292.

Post, K. 1931. Reducing the day length of
Chrysanthemums for the production of early blooms by the use of black sateen cloth. Procee. Am. Soc. Horti. Sci. 28: 382-388.

Piringer, A.A., and Cathey, H.M. 1960. Effect of photoperiod, kind of supplemental light and temperature on the growth and flowering of Petunia plants. Proc. Am. Soc. Horti. Sci. 76:649-660.

Thimijan, R.W., and Heins, R.D. 1983. Photometric, radiometric, and quantum light units of measure: a review of procedures for interconversion. Hortsci.18: 818822.

Van Der Ploeg, A., and Heuvelink, E. 2006. The influence of temperature on growth and development of Chrysanthemum cultivars: a review. J. Hort. Sci. Biotech., 81(2): 174-182.

Yamada, A., Tanigawa, T., Suyama, T., Matsuno, T., and Kunitake, T. 2008. Night break treatment using different light source promotes or delay growth and flowering of Eustoma grandiflorum (Raf.). Shinn J. Japan Soc. Horti. Sci.77: 69-70.

\section{How to cite this article:}

Tanya Thakur and Grewal, H.S. 2018. Influence of Photoperiodic Night Interruption on Sustainable Potted Flower Production of Chrysanthemum cv. Snowball. Int.J.Curr.Microbiol.App.Sci. 7(02): 1282-1287. doi: https://doi.org/10.20546/ijcmas.2018.702.156 